\title{
Accomplices in Federal Court: A Case for Increased Evidentiary Standards
}

\author{
Christine J. Saverda †ิ
}

Only reliable evidence should support criminal convictions. ${ }^{1}$ The federal courts $^{2}$ and Congress ${ }^{3}$ have, accordingly, voiced their condemnation of perjury in criminal trials when suborned by prosecutorial misconduct and have developed sanctions for perjury. ${ }^{4}$ Yet existing sanctions and strictures have proved inadequate in detecting and curtailing the numerous instances of perjury ${ }^{5}$ that result when the government, via the prosecutor, entices a witness to testify in return for some type of consideration. ${ }^{6}$ Whether in the form of a more lenient sentence, a dropped charge, or immunity, in practical terms these promises are really rewards offered by the prosecution. ${ }^{7}$ Because the prosecution actually induces the testimony, the government should make a forthright attempt to ensure that the ensuing testimony is void of falsity. Perjury ${ }^{8}$ not only threatens the accuracy of the factfinding process but insidiously undermines the entire

$\dagger$ The author wishes to dedicate this Note to the memory of her father, Edward J. Saverda, who missed its publication by a few months.

1. Ohio v. Roberts, 448 U.S. 56, 66 (1980) (confrontation clause of Sixth Amendment ensures some certainty in criminal trials by permitting only reliable hearsay to come before trier of fact).

2. The Supreme Court has held that knowing use of false testimony by prosecutors is a denial of the defendant's due process right to a fair trial. See, e.g., United States v. Agurs, 427 U.S. 97, 103 (1970).

3. The sanction for subornation of perjury is a fine of $\$ 2,000$, imprisonment for five years, or both. 18 U.S.C. § 1622 (1988).

4. The sanction for perjury in the federal courts is a fine of $\$ 2,000$, imprisonment for five years, or both. 18 U.S.C. § 1621 (1988).

5. See Note, I Cannot Tell a Lie: New Trial Standard in False Testimony Cases, 83 Mich. L. REv. 1925 (1985) [hereinafter Note, New Trial Standard]. See generally infra notes 14-15 and accompanying text.

6. See cases and sources cited infra note 10 .

7. One commentator writes:

[P]romises of favorable treatment differ fundamentally from other forms of potentially exculpatory or impeaching evidence. The prosecutor, or his agent, discovered the eyewitness, the glass covered with fingerprints, and the evidence reflected in the police report. These items existed independently of the prosecutor's initiative. A promise of favorable treatment, however, exists only because of the prosecutor's deliberate action. The prosecutor, taking advantage of a power conferred on him but denied to the defendant, has himself provided a motive to lie.

Note, A Prosecutor's Duty to Disclose Promises of Favorable Treatment Made to Witnesses for the Prosecution, 94 HARV. L. REV. 887, 895 (1981) [hereinafter Note, A Prosecutor's Duty to Disclose]; see also Note, New Trial Standard, supra note 5, at 1942-43 (asserting that even though prosecutor may be unaware of perjury, she has taken action to induce false testimony by offering favorable treatment).

8. Although perjury may occur throughout the entire adjudicative process, this Note addresses only the perjury problems inherent in accomplice testimony. See infra note 21 for definition of perjury. 
criminal justice system by attenuating the societal respect necessary for maintaining the system's viability. ${ }^{9}$

Generally, the beneficiaries of prosecutorial inducement to testify are accomplices turned informers, who frequently are granted immunity premised upon their acquiescence in testifying against the accused. ${ }^{10}$ Accomplices are typically considered to be those who are or could have been indicted for the same crime, arising out of the same events, as the defendant. ${ }^{11}$ Their testimony, in contrast to that of other prosecution witnesses such as paid informers, ${ }^{12}$ must be afforded special scrutiny for two reasons. First, the accomplice has especially compelling reasons to testify on his own behalf. He will often have pleaded guilty, or have agreed to plead guilty, to the offense or a related offense, and will be awaiting sentencing. It is in his interest not only to implicate others but to minimize his own role and exaggerate the roles of his coconspirators. He may, on the other hand, have escaped indictment on the charges by telling a story which exonerates himself and shifts the blame to the accused. In short, his sanctuary may depend upon the self-serving nature of his story.

Second, an accomplice claims to have participated in the intricacies of the crime alleged. Thus he portrays himself as having firsthand knowledge of the illegal act as well as being the witness most capable of relating the details of the criminal activity to the jury. This claim to "inside knowledge," coupled with the fact that his testimony is usually the most damaging evidence against the defendant, allows the accomplice to deviate from the truth without arousing the

9. In a national public opinion survey, high school seniors were asked if the courts and judicial system in general had problems of dishonesty and immorality. Twenty-three percent of the respondents felt the problems were considerable or great. DEPARTMENT OF JUSTICE, SOURCEBOOK OF CRIMINAL JUSTICE STATISTICS, 245 table 2.68 (1988).

See also United States v. Norris, 300 U.S. 564, 574 (1937) ("Perjury is an obstruction of justice; its perpetration may well affect the dearest concerns of the parties before a tribunal."); Comment, Perjury: The Forgotten Offense, 65 J. CRMM. L. \& CRIMnOLOGY 361 (1974) [hereinafter Comment, The Forgotten Offense] (arguing that perjury impedes administration of justice as a whole as well as particular dispute, and diminishes society's respect for judicial system); Shellenberger, Perjury Prosecutions Afier Acquittals: The Evils of False Testimony Balanced Against the Sanctity of Determinations of Innocence, 71 MARQ. L. REV. 703 (1988) (arguing that stability of our criminal justice system hinges upon public respect and approval).

10. See, e.g., United States v. McCabe, 720 F.2d 951, 952 (7th Cir. 1983) (co-conspirators testified against defendant on charges of marijuana distribution as part of plea agreements); United States v. Leonard, 494 F.2d 955 (D.C. Cir. 1974) (on charges of murder and armed robbery, some defendants granted immunity in exchange for testimony against another defendant); Giglio v. United States, 405 U.S. 150 (1972) (in exchange for testimony, prosecutor agreed not to indict co-conspirator in plot to pass forged money orders).

Prosecutorial use of plea bargain agreements to gain testimony of accomplice and informant witnesses is considered to be rampant. See Nemerson, Coercive Sentencing, 64 MINN. L. REv. 669, 679 (1980) (lenient treatment is great lure for informants); Note, A Prosecutor's Duty to Disclose, supra note 7, at 888-89 (contending that most persuasive inducement for individuals to agree to act as informers is lenient treatment for their own criminality).

11. See Orfield, Corroboration of Accomplice Testimony in Federal Criminal Cases, 9 VILL. L. REV. 15 , at $25 \mathrm{n.84}$ (1963).

12. Although arguments can be made for extending corroboration requirements to other prosecution witnesses-for example, paid and jailhouse informants trying to reduce their sentences-the dangers peculiar to their testimony raise issues beyond the scope of this Note. 
jury's suspicion. Since the accomplice alone knows about the pattern of criminal events, he can manipulate the details of those events without blatant discrepancies. In effect, then, little room remains to question the veracity of his testimony. Thus, his testimony proposes a unique danger: the increased probability that a jury will, unquestioningly and with little scrutiny, accept his story as true because of its inherent "believability." 13

This Note asserts that the federal system should follow the example of a number of state jurisdictions ${ }^{14}$ and establish corroboration requirements for accomplice testimony in criminal trials in order to reduce an accomplice's opportunity to fabricate testimony, as well as set out evidentiary parameters to restrain prosecutorial zeal. Part I of the Note illustrates the incentives for an accomplice to lie under the present federal system. Part II details the treatment afforded accomplice testimony on the state and federal levels and analyzes the recent evolution of federal standards. Part III focuses upon the inadequacies of the federal system in curtailing false testimony by accomplices and protecting the innocent. Part IV proposes that the federal courts adopt corroboration requirements for accomplice testimony and that federal judges provide cautionary instructions to the jury when an accomplice testifies.

\section{Minimal DETERRENCE OF AND INCREASED INCENTIVES FOR FALSEHOOD UNDER THE CURRENT SYSTEM}

The fact that accomplice testimony is presumptively unreliable has never been disputed..$^{15}$ Moreover, the federal courts and the legal community have repeatedly recognized that the chances of perjury are increased when an accomplice testifies in exchange for consideration. ${ }^{16}$ Despite these revelations and because legislative provisions are absent, the courts have steadfastly refused

13. The jury's ability to determine when a witness is lying is questionable. In fact, some experts believe that a juror's acceptance of false testimony hinges on the witness's ability to lie convincingly. Wolfram, Client Perjury, 50 S. CAL. L. REv. 809, 834 (1977).

14. See infra notes $45-47$ and accompanying text.

15. The Supreme Court has viewed accomplice testimony as suspect and unreliable. Bruton v. United States, 391 U.S. 123, 136 (1968); On Lee v. United States, 343 U.S. 747, 757 (1952); Caminetti v. United States, 242 U.S. 470, 495 (1917). Lower courts also have expressed this view. See, e.g., United States v. McCabe, 720 F.2d 951, 956 (7th Cir. 1983); United States v. Leonard, 494 F.2d 955, 960 (D.C. Cir. 1974).

16. See, e.g., Boone v. Paderick, 541 F.2d 447, 451 (4th Cir. 1976) (when accomplice is aware that testimony can reduce his own charge, incentive to please promisor increases); McMillen v. United States, 386 F.2d 29, 36 (1st Cir. 1967) (accomplices extended plea bargain contingent upon testimony are not free from carrot or stick); United States v. Baresh, 595 F. Supp. 1132, 1134 (S.D. Tex. 1984) (accomplice well aware that if testimony did not result in defendants' convictions, his state charges would not be dropped); Note, A Prosecutor's Duty to Disclose, supra note 7, at 890 \& n.19 (citing United States v. Meinster, 619 F.2d 1041, 1044-45 (4th Cir. 1980)); Note, New Trial Standard, supra note 5, at 1942 n.63 (indicating that of the 50 cases involving allegations of false testimony surveyed in the Note, nearly two-thirds involved the testimony of co-conspirators or informant witnesses); see also Note, Accomplice Testimony Under Contingent Plea Agreements, 72 CORNELL L. REV. 800, 825 n.146 (1987) (hereinafter Note, Contingent Plea Agreements] ("[T]his case demonstrates the potential for injustice which is inherent in selling an admitted felon leniency, in order to buy testimony against another. . . .") (citing Franklin v. State, 94 Nev. 220, 223 n.2, 577 P.2d 860, 861 n.2 (1978)). 
to require corroboration of an accomplice's testimony and have upheld convictions based upon the uncorroborated testimony of accomplices. ${ }^{17}$ Not only does the judicial system fail to deter accomplice perjury but, as the following subsections will show, it actually provides incentives for an accomplice to testify falsely.

\section{A. The Perjury Sanction and Its Limited Effect}

Many commentators believe that perjury is pervasive in our criminal justice system. ${ }^{18}$ The perjury sanction-the institutional safeguard created to guard against false testimony - represents a minimal deterrent, however, since perjury prosecutions are rarely brought. ${ }^{19}$ In fact, a report prepared by the Department of Justice shows that in 1987 , only $.003 \%$ of federal prosecutions were for perjury. ${ }^{20}$

The primary reason for the failure to enforce perjury statutes is the difficulty in proving the crime due to evidentiary technicalities. ${ }^{21}$ No matter what the reason, the nonenforcement of perjury sanctions has detrimental effects. ${ }^{22}$ Society may view the failure to initiate cases as prosecutorial acceptance of perjury. At a minimum, society may construe nonenforcement as an indication that the crime is trivial. Furthermore, the prospective perjurer will not be deterred in the absence of potential sanctions for her behavior. ${ }^{23}$ In many cases involving uncorroborated accomplice testimony, the accomplice realizes that only she can account for the veracity of her statements. Armed with the knowledge that digressions from the truth probably will not be discovered, and that if discovered, are unlikely to result in prosecution, the accomplice is free to lie without worry.

17. See, e.g., Caminetti v. United States, 242 U.S. 470, 495 (1917); United States v. Anderson, 654 F.2d 1264, 1268 (8th Cir. 1981).

18. See Wolfram, supra note 13 , at 813 n.13. See generally supra note 8 \& infra note 19.

19. Note, Perjury by Defendants: The Uses of Double Jeopardy and Collateral Estoppel, 74 HARV. L. REV. 752 n.1 (1961); see also Shellenberger, supra note 9, at 709; Comment, The Forgotten Offense, supra note 9 , at $361-71$.

20. Department of Justice, supra note 9, at 554 table 5.27, 556 table 5.28 (1988).

21. Perjury occurs when a person swears willfully and falsely to a material matter under oath. 18 U.S.C. $\S 1621$ (1988). Evidentiary technicalities which may account for the limited number of perjury prosecutions include materiality - proof that the testimony could have or did influence the verdict-and the requirement that falsity must be proved by the testimony of two independent witnesses, or by one witness and independent corroborative evidence. See Shellenberger, supra note 9, at 710-11.

22. See supra note 9 and accompanying text.

23. In the words of another writer, "If inaccurate or unjust results based on false testimony are believed to be the norm, people will avoid the system altogether. Instead, they will resort to their own means of resolving disputes, or they will simply resort to their own false testimony, with increasingly dire consequences." Shellenberger, supra note 9, at 706 (footnote omitted). 


\section{B. Immunity and Contingent Plea Agreements}

Currently, the federal statute governing immunity is the Witness Immunity Act of $1970,{ }^{24}$ which provides for "use" immunity only. Use immunity allows a prosecutor to compel the testimony of a witness over a Fifth Amendment claim, but prohibits the use of the compelled testimony to develop or try a case against the witness..$^{25}$ Use immunity is distinct from transactional immunity, the type previously offered by the federal government, in which the witness was afforded complete immunity from prosecution for any transaction mentioned in the compelled testimony. ${ }^{26}$ With the advent of use immunity, requests for immunity have surged ${ }^{27}$ In fact, more witnesses were immunized under the Witness Immunity Act of 1970 during the first ten months of its existence than were immunized during the preceding fifty years of transactional immunity. ${ }^{28}$ In addition to formal use immunity, prosecutors can also offer informal immunity to a witness in the form of a proffer or letter promising not to prosecute. ${ }^{29}$

Proponents of immunity defend it as a useful governmental investigatory tool for the prosecution of conspirators and white collar criminals. ${ }^{30}$ As a result, prosecutors have what has been referred to as "unbridled authority" to grant immunity. ${ }^{31}$ Wielded daily by prosecutors, this powerful tool provides a rich opportunity for accomplices desiring favorable treatment in exchange for testimony. An accomplice doubtless feels that immunity will not be proffered unless the prosecuting attorney believes that his testimony will incriminate the defendant. ${ }^{32}$ Thus, in many cases, an accomplice has a strong impetus to lie in order to satisfy the prosecutor. Realistically, he does not have to fear a subsequent prosecution based upon this testimony because a heavy burden is

24. 18 U.S.C. § 6001-6005 (1985).

25. 18 U.S.C. § 6003 (1985).

26. Transactional immunity was formerly governed by Act of July 18,1956 , ch. $629, \S 1406,70$ Stat. 574 (repealed 1970).

27. The percentage of prosecutorial requests for grants of immunity has steadily increased from $42 \%$ in 1973 to 50\% in 1988. DEPARTMENT OF JUSTICE, supra note 9, at 528 table 5.1. Arguably, requests for use immunity have increased because use immunity is much more limited than transactional immunity. Under use immunity, the government cannot use the information derived from the compelled testimony to prove a crime against the witness in a later criminal proceeding; transactional immunity precludes any subsequent prosecution of the witness for all crimes related to his compelled testimony. Understandably, then, prosecutors are more predisposed to offer use immunity. See Note, Balancing the Interests Involved in Granting Defense Witness Immunity, 45 ALB. L. REV. 800, 802 n.13 (1981) (noting that increase in prosecutorial requests for immunity coincides with proliferation of limited immunity statutes).

28. Scandurro, Immunity, 24 AM. CRIM. L. REV. 839, 839 n.3 (1987).

29. For a description of informal immunity and its acceptance by federal courts, see Comment, Current Controversies Concerning Witness Immunity in the Federal Courts, 27 VILL. L. REV. 123, 140-41 (1981). Informal immunity is made possible by the broad discretionary power vested in the United States Attorney. See United States v. Quatermain, 613 F.2d 38, 41 (3d Cir.), cert. denied, 446 U.S. 954 (1980).

30. Mykkeltvedt, United States v. Alessio-Due Process of Law and Federal Grants of Witness Immunity for Defense Witnesses, 31 MERCER L. REV. 689, 690 (1980); Scandurro, supra note 28, at 839.

31. L. TAYLOR, WITNESS IMMUNITY 53-54 (1983) (Justice Department routinely approves requests for immunity).

32. See Note, A Prosecutor's Duty to Disclose, supra note 7, at 890 (prosecutors make promises of favorable treatment specifically for their anticipated impact on accomplice's testimony). 
placed upon the government to prove that a subsequent prosecution related to the compelled testimony was derived solely from evidence obtained independent of his testimony. ${ }^{33}$ Furthermore, although the Witness Immunity Act expressly provides that immunized testimony may be used against a witness in a perjury prosecution, ${ }^{34}$. as noted above, prosecutions for perjury are rarely initiated. ${ }^{35}$

In addition to the ample incentive for false testimony provided by the widespread use of immunity, the use and acceptance of contingent plea agreements can further lure an accomplice to testify untruthfully, or at least to embellish some aspects of her testimony. Contingent plea agreements are those in which the prosecutor conditions an accomplice's leniency upon another defendant's indictment or conviction, or the prosecution's satisfaction with the accomplice's testimony. ${ }^{36}$ If the accomplice does not testify fully and truthfully, the prosecutor may refuse the favorable treatment promised in the bargain. ${ }^{37}$ Most courts have accepted these contingent arrangements in upholding convictions founded upon accomplice testimony and have held that a defendant's right to a fair trial is not violated even when she claims that a plea agreement so encouraged systematic perjury that cross-examination could not rectify the damage incurred. ${ }^{38}$

\section{HISTORIC TREATMENT OF ACCOMPLICE TESTIMONY}

\section{A. State Treatment of Accomplice Testimony}

Nearly all states view accomplice testimony with suspicion due to the belief that accomplices often implicate their co-conspirators in order to exculpate themselves. ${ }^{39}$ As a result of this perceived unreliability, many states have enacted statutes mandating corroboration of an accomplice's testimony to

33. The burden placed upon the government results from proceedings called "Kastigar hearings," pretrial hearings in which the defense counsel attempts to dismiss the indictment claiming that the government wrongfully used immunized testimony. The burden of proof is upon the government to show that all the evidence it intends to use for a prosecution based upon immunized testimony was obtained solely from independent sources. The burden is, no doubt, a heavy one. Kastigar v. United States, 406 U.S. 441, 460 (1972) (government bears heavy burden of proving that evidence was obtained independently).

34. 18 U.S.C. $\S 6002$ (1985).

35. See sources cited supra note 19.

36. See generally Note, Contingent Plea Agreements, supra note 16 (analysis and criticism of contingent plea agreements). For examples of the use of contingent plea agreements, see United States v. Boley, 730 F.2d 1326 (10th Cir. 1984); United States v. Librach, 536 F.2d 1228 (8th Cir.), cert denied, 429 U.S. 939 (1976).

37. Of course, testifying truthfully may just be a euphemism for making the prosecutor happy.

38. See, e.g., United States v. Spector, 793 F.2d 932, 936-37 (8th Cir. 1986), cert. denied, 479 U.S. 1031 (1987); United States v. Dailey, 589 F. Supp. 561 (D. Mass. 1984). But see United States v. Baresh, 595 F. Supp. 1132 (S.D. Tex. 1984) (plea bargain so conducive to perjury that admitting testimony violated due process).

39. See, e.g., State v. Pierce, 107 Idaho 96, 101, 685 P.2d 837, 842 (Ct. App. 1984); Glaze v. State, 565 P.2d 710, 712 (OkJa Crim. App. 1977); 7 J. WIGMORE, EVIDENCE IN TRIALS AT COMMON LAW § 2057, at 417 (1978). 
sustain a conviction..$^{40}$ Another has added the requirement by judicial decision. ${ }^{41}$ Corroborative evidence is usually considered to be that which, when viewed independent of the accomplice, would tend to connect the defendant with the commission of the crime charged. ${ }^{42}$ The existence of corroboration is usually a threshold question for the judge; if found, she may then submit the accomplice testimony to the jury. ${ }^{43} \mathrm{~A}$ corollary to actual corroboration in those states where it is mandatory is the requirement that the trial judge instruct the jury of the need for corroboration and of the need to view accomplice testimony with caution. In some states, refusal to give these instructions requires reversal. $^{44}$

To avoid ambiguity, states requiring corroboration have provided a definition for accomplice. Usually, an accomplice is defined as one who is or could have been indicted for the same crime, arising out of the same events, as the accused ${ }^{45}$ If the status of a witness is uncontroverted, the judge can determine as a matter of law that she is an accomplice. On the other hand, if the witness' status is disputed, her classification as an accomplice becomes a question of fact to be decided by the jury. ${ }^{46}$

40. Currently, 16 states and territories have accomplice corroboration statutes. ALA. CODE $§ 12-21-222$ (1986) (applies to felonies only); ALASKA STAT. $\$ 12.45 .020$ (1984); ARK. STAT. ANN. § 16-89-111(e)(1) (1977) (applies to felonies only); CAL. PENAL CODE § 1111 (West 1985); GA. CODE ANN. § 24-4-8 (1982) (rule applies to treason, perjury, and felonies, but only when accomplice is sole witness); IDAHO CODE § 19-2117 (1979); IOWA CODE ANN. § 813.2 (R.20(3)) (West 1979 \& Supp. 1990); MNN. STAT. ANN. § 634.04 (1983); MONT. CODE ANN. \$46-16-213 (West 1985); NEV. REV. STAT. § 175.291 (1985); N.Y. CRM. PROC. LAW § 60.22 (McKinney 1981); N.D. CENT. CODE § 29-21-14 (1974); OKLA. STAT. ANN. tit. 22, $\S 742$ (West 1969); OR. REV. STAT. § 136.440 (1984); P.R. LAWS ANN. tit. 34, App. II, R.156 (Supp. 1988); S.D. CODIFIED LAWS ANN. \$ 23A-22-8 (1979); TEX. CRM. PROC. CODE ANN. art. 38.14 (Vernon 1979). However, since 1973, seven states and territories have withdrawn their requirements. ARE. REV. STAT. ANN. § 13-136 (repealed 1976); KY. REV. CRM. PROC. CODE 9.26 (repealed 1980); N.H. REV. STAT. ANN. § 579:4 (repealed 1973); OHIO REV. CODE ANN. \$ 2903.03(d) (repealed 1989) (rule replaced with mandatory cautionary jury instruction); UTAH CODE ANN. \& 77-31-18 (superseded 1979); V.I. CODE ANN. tit. 14, § 7 (refealed 1978); WYO. STaT. § 7-6-262 (repealed 1975).

41. The corroboration rule has been established by judicial decision in Tennessee State v. Copeland, 677 S.W.2d 471, 474 (Tenn. Crim. App. 1984), (citing McKinney v. State, 552 S.W.2d 787 (Tenn. Crim. App. 1971)). Even where the common law recognizes no corroboration requirement, however, the use of accomplice testimony is strictly limited due to the suspicious nature of the testimony. 23 C.J.S. Criminal Law \$ 810(1)(b) (1961).

42. See, e.g., Cunningham v. State, 54 Ala. App. 656, 658, 312 So. 2d 62, $63-64$ (Crim. App. 1975) (in prosecution for grand larceny, testimony and identification of pawn shop dealer, testimony of victims, and evidence of handwriting and signatures held sufficient to connect defendant with crime); Thompson v. State, 691 S.W.2d 627, 631 (Tex. Crim. App. 1984) (en banc) (in prosecution for murder, testimony of nonaccomplice witnesses including neighbor, acquaintance, and police officer held sufficient to connect defendant with crime).

43. See, e.g., Leonard v. State, 43 Ala. App. 454, 464-65, 192 So. 2d 461, 470-71 (1966); 7 J. WIGMORE, supra note $39, \S 2059$, at 438 .

44. See, e.g., People v. Harrell, 281 A.D. 690, 117 N.Y.S.2d 199, 200 (1952); People v. Wallin, 32 Cal. 2d 803, 197 P.2d 734 (1948).

45. See, e.g., People v. Beaudet, 32 N.Y.2d 371, 374-75, 298 N.E.2d 647, 649, 345 N.Y.S.2d 495, 498 (1973); Leonard v. State, 43 Ala. App. 454, 463, 192 So. 2d 461, 469 (1966).

46. State v. Thorson, 264 N.W.2d 441, 442 (N.D. 1978); see also cases cited supra note 45. 
Although state accomplice statutes vary considerably, ${ }^{47}$ the mere existence of legislation defining corroboration and accomplice status illustrates some states' laudable goal of establishing evidentiary guidelines when dealing with potentially unreliable testimony that could result in unwarranted convictions. ${ }^{48}$ Despite attacks by some politicians and commentators, legislatures in these states have adhered to the view that the danger of allowing convictions based upon uncorroborated accomplice testimony outweighs the harm caused by letting some guilty defendants go free. ${ }^{49}$

\section{B. Federal Treatment of Accomplice Testimony}

In 1909, the Supreme Court observed in Crawford v. United States ${ }^{50}$ that accomplice testimony "ought to be received with suspicion, and with the very greatest care and caution, and ought not to be passed upon by the jury under the same rules governing other and apparently credible witnesses." Despite this recognition that accomplice testimony is less credible than disinterested witness testimony, the following year, in Holmgren $v$. United States, ${ }^{51}$ the Supreme

47. Cal. Penal CoDe $\S 1111$ (West 1985) states:

A conviction cannot be had upon the testimony of an accomplice unless it be corroborated by such other evidence as shall tend to connect the defendant with the commission of the offense; and the corroboration is not sufficient if it merely shows the commission of the offense or the circumstances thereof.

An accomplice is hereby defined as one who is liable to prosecution for the identical offense charged against the defendant on trial in the cause in which the testimony of the accomplice is given. A much broader definition of accomplice appears in N.Y. CRM. PROC. LAW $\S 60.22$ (McKinney 1981), which states in part:

1. A defendant may not be convicted of any offense upon the testimony of an accomplice unsupported by corroborative evidence tending to connect the defendant with the commission of such offense.

2. An "accomplice" means a witness in a criminal action who, according to evidence adduced in such action, may reasonably be considered to have participated in:

(a) The offense charged; or

(b) An offense based upon the same or some of the same facts or conduct which constitute the offense charged.

The fact that both New York and California-two states with extremely large criminal dockets-have corroboration requirements, supports the contention that a judicial system with a higher evidentiary standard can function devoid of detrimental effects.

48. In People v. Cona, 424 N.Y.S.2d 146, 399 N.E.2d 1167, 1170 (1979), the court stated:

The accomplice corroboration rule is premised upon a legislative determination that the testimony of individuals who may themselves be criminally liable is inherently suspect. This is deemed to be true because such individuals may be subject to pressures impelling them to color testimony in order to protect themselves by belittling the actual extent of their involvement in the criminal enterprise at the expense of others. In a similar vein, a person who agrees to turn State's evidence may believe it to be in his best interests to embellish the truth .... .

49. "In 1937, the New York Commission on the Administration of Justice unsuccessfully recommended to the legislature the repeal of the statutory rule requiring accomplice corroboration." The committee opined that the rule was a refuge for principals in organized crime and racketeering cases. Note, Corroboration in the New York Criminal Law, 24 BROOKLYN L. REV. 324, 343 n.116 (1957). Despite the committee's recommendation, New York has retained, quite firmly, its corroboration requirement. More recent attacks upon the state's corroboration rules are premised upon the expansive definition of accomplice.

50. 212 U.S. 183, 204 (1909).

51. 217 U.S. 509,524 (1910). 
Court refused to reverse a judgment for failure to give a jury instruction on the inherently suspect nature of accomplice testimony. ${ }^{52}$ The Court admonished that it was "the better practice for courts to caution juries against too much reliance upon the testimony of accomplices," but for unexplained reasons, failed to conclude that an instruction was mandatory. ${ }^{53}$ Against this background came the 1917 decision in Caminetti v. United States, ${ }^{54}$ in which the Court overlooked California state law in ruling that corroboration of accomplice testimony was not required in the federal courts.

Both the Caminetti and Holmgren decisions appear to be at odds with Crawford. Neither provided a reason for avoiding a per se rule requiring corroboration of accomplice testimony. One can only speculate as to why the Court first suggested that accomplice testimony was deserving of special treatment by the jury, yet less than a decade later, resisted establishing mandatory rules requiring cautionary jury instructions and corroboration. The Caminetti decision, and to some extent the Holmgren decision, highlighted an ongoing jurisprudential debate about the treatment that should be afforded accomplice testimony. The controversy resurfaced once again in 1944 when the drafters of the Federal Rules of Criminal Procedure recommended implementation of corroboration rules similar to those existing in the State of California. ${ }^{55}$ Ultimately, the proposal was rejected in the same year. ${ }^{56}$ Accordingly, the federal courts for some time continued to adhere unquestioningly to the Caminetti holding that corroboration of accomplice testimony is not required..$^{57}$

In Audett v. United States, ${ }^{58}$ a 1959 case, the Ninth Circuit, in reviewing a request by defense counsel, refused to mandate corroboration of accomplice testimony. The court stated that the existing federal standard was consonant with the belief that "the testimony of one witness, if believed [by the jury], is sufficient to prove a fact." ${ }^{\text {59 }}$ The Audett court included Caminetti and Holmgren in its list of cases supporting the firmly established rule..$^{60}$ Yet, as noted previously, both of these decisions were devoid of any explanation as to why corroboration of accomplice testimony should not be required. ${ }^{61}$ The principal basis for the court's reasoning in Audett appears to be Wigmore's

52. Cf. Fried v. United States, 266 F. 1012, 1016 (1920) (reversal required when jury instruction not given).

53. 217 U.S. at 524. The Court did state that the requested instruction in this case was improper.

54. 242 U.S. 470, 495 (1917).

55. Orfield, The Reform of Federal Criminal Evidence, 32 F.R.D. 121, 130-131 (1963).

56. Id. To date, the federal rules do not address the subject of accomplice corroboration.

57. See, e.g., United States v. Anderson, 654 F.2d 1264, 1268 (8th Cir. 1981); United States v. Sabin, 526 F.2d 857, 859 (5th Cir. 1976); Audett v. United States, 265 F.2d 837, 847 (9th Cir.), cert. denied, 361 U.S. 815 (1959).

58. 265 F.2d 837, 846-47 (9th Cir.), cert. denied, 361 U.S. 815 (1959).

59. Id. at 847 (citing $7 \mathrm{~J}$. WIGMORE, EVIDENCE $§ 2034$ (3d ed. 1940)).

60. Id. at 847 n.46.

61. See supra text accompanying notes $51-57$. 
treatise on evidence, in which he condemns any policy that would undermine the practice of allowing the jury to decide questions of credibility. ${ }^{62}$

The Supreme Court in 1967 eventually enunciated a rationale for excluding corroboration requirements for accomplice testimony in Washington v. Texas. ${ }^{63}$ After tracing the common law standard that erroneous decisions were best avoided by preventing the jury from hearing testimony that might be perjured, the Court nonetheless opined that the truth is more likely to be ascertained by allowing the jury to hear the testimony of all competent persons having knowledge of the facts and to determine the credit and weight to be given each individual's testimony. ${ }^{64}$

Although conceding that the jury should determine credibility and that the testimony of an accomplice can be sufficient to establish a fact, the courts nevertheless continued to voice their distrust of accomplice testimony and its susceptibility to perjury. ${ }^{65}$ Eventually, however, modern standards governing the sufficiency of accomplice testimony were established by judicial fiat, presumably because of the danger attributable to accomplice testimony. ${ }^{66}$

The modern movement toward limiting the sufficiency of uncorroborated accomplice testimony began with Haakinson $v$. United States, ${ }^{67}$ a case that introduced the catchall phrase that a conviction may be based solely upon the testimony of an accomplice if the testimony is not "unsubstantial or incredible on its face." ${ }^{18}$ Since, however, the Haakinson court did not define the parameters for determining when testimony is "incredible" or "unsubstantial," it left subsequent courts with the task of applying this ambiguous standard. As the case law has developed, some judges perfunctorily review the facts uncovered at the trial level and conclude, without detailed analysis, that an accomplice's testimony is credible. ${ }^{69}$ But in most applications of the standard, the courts implicitly construe "incredible" or "unsubstantial" as synonymous with uncor-

62. Audett v. United States, 265 F.2d 837, 847 (9th Cir.), cert. denied, 361 U.S. 815 (1959) (citing 7 J. WIGMORE, EVIDENCE $\S 2057$ (3d ed. 1940)).

63. 388 U.S. 14 (1967).

64. Id. at 22 .

65. See, e.g., Lee v. Illinois, 476 U.S. 530, 542 (1986) ("IA] confession that incriminates an accomplice is so 'inevitably suspect' and 'devastating' that the ordinarily sound assumption that a jury will be able to follow faithfully its instructions can not be applied." (citing Bruton v. United States, 391 U.S. 123, 136 (1968))); United States v. Lee, 506 F.2d 111, 120 (D.C. Cir. 1974) ("When there is no corroboration, the problem of perjury looms large ... .”; Phelps v. United States, 252 F.2d 49, 52 (5th Cir. 1958) ("A skeptical approach to accomplice testimony is a mark of the fair administration of justice .... [A] long history of human frailty and governmental overreaching for conviction justifies distrust in accomplice testimony.").

66. See cases cited infra notes 69-76.

67. 238 F.2d 775 (8th Cir. 1956).

68. Id. at 779 .

69. See, e.g., Moody v. United States, 376 F.2d 525, 528 (9th Cir. 1967) ("It is clear from the many decisions of this court... that a conviction in Federal court can be based upon the uncorroborated testimony of an accomplice."); Lyda v. United States, 321 F.2d 788, 794-95 (9th Cir. 1963) ("In federal courts a conviction may be based on the uncorroborated testimony of an accomplice."). 
roborated. ${ }^{70}$ Thus, when concluding that testimony is credible, these courts have pointed to the corroborative evidence present.

Judicial recognition that accomplice testimony is distinct from other testimony has also caused a move toward the use of cautionary jury instructions. In 1915, the Ninth Circuit noted in Diggs $v$. United States that it had discovered no cases in which it was considered reversible error to refuse a request for a cautionary jury instruction. ${ }^{71}$ Retreat from this carte blanche attitude began in 1958 with Phelps v. United States, ${ }^{72}$ when the Fifth Circuit reversed a conviction based upon the refusal to provide the requested accomplice instructions. The Phelps court was quick to note, however, that reversal is not always required, and that the decision to reverse should only be made upon a review of the facts. ${ }^{73}$

Recently, when reviewing rulings on requests for cautionary instructions, some courts have distinguished between two classes of cases when the testimony serves as a major portion of the convicting evidence: those in which corroborating evidence is present, and those in which such evidence is lacking. In the former situation, failure to give a cautionary instruction has not been found to be reversible error, ${ }^{74}$ while in the latter, some courts have reversed. ${ }^{75}$ When no instruction was requested, some courts have looked to the facts of the case to see if corroborating evidence obviated the need for instructions. $^{76}$

In sum, the majority of courts appear to be applying an "either/or" standard: Either corroboration must be demonstrated, or the jury must be cautioned when weighing the accomplice's testimony. Undoubtedly, this new approach reflects dissatisfaction with antiquated rules and is indicative of courts' belief that in some cases, the use of accomplice witnesses should be curtailed to protect against prevaricated testimony. But, as discussed in the next part, the "either/or" standard is problematic and fraught with difficulty.

70. See, e.g., United States v. Kragness, 830 F.2d 842, 866 (8th Cir. 1987); United States v. Sigal, 572 F.2d 1320, 1324 (9th Cir. 1978); Tillery v. United States, 411 F.2d 644, 647-48 (5th Cir. 1969). Note that most of these courts use the term "insubstantial" rather than "unsubstantial."

71. Diggs v. United States, 220 F. 545, 552 (9th Cir.1915), aff' $d$ sub nom. Caminetti v. United States, 242 U.S. 470 (1917).

72. 252 F.2d 49 (5th Cir. 1958).

73. Id. at 53; see also Tillery v. United States, 411 F.2d 644, 647 (5th Cir. 1969).

74. United States v. Lee, 506 F.2d 111, 120 (D.C. Cir. 1974) (testimony "materially" corroborated); United States v. Williams, 463 F.2d 393, 395-96 (10th Cir. 1972) ("considerable" evidence corroborated testimony); Christy v. United States, 261 F.2d 357, 361 (9th Cir. 1958) ("ample" corroborating testimony).

75. United States v. Hill, 627 F.2d 1052, 1053-55 (10th Cir. 1980) (corroborating evidence insufficient); Tillery, 411 F.2d at 647-48 (no corroboration of accomplice testimony that was major evidence against accused); Phelps v. United States, 252 F.2d 49, 53-54 (5th Cir. 1958) (jury not given chance to test credibility of accomplice testimony that was only evidence linking defendant to crime). But see United States v. McCabe, 720 F.2d 951, 956-57 (7th Cir. 1983) (refusal to give instruction not erroneous because interests of accomplices were exposed to jury).

76. McCabe, 720 F.2d at 956-57; Hill, 627 F.2d at 1053-55; Tillery, 411 F.2d at 646; McMillen v. United States, 386 F.2d 29, 36 (1st Cir. 1967). 


\section{InADEQUACIES OF THE Federal System AND THE NEED FOR REFORM}

The most evident problems with the current corroboration standards derive from Haakinson and its progeny. ${ }^{77}$ Many of these cases have implied that a conviction cannot be sustained if corroboration is lacking. Despite this implication, however, and in the absence of a clear rule, trial courts do not consistently require corroboration of accomplice testimony. As a result, the jury does not necessarily evaluate the accomplice's credibility or determine the weight to be given her testimony in accordance with the "incredible or unsubstantial" test, for it has not been instructed to do so. The result is that jury verdicts are reversed when appellate courts apply the "incredible or insubstantial" standard, a task that requires the appellate courts, rather than the jurors, to weigh evidence and testimony. Consequently, the predominant rationale for not having mandatory corroboration requirements-that the jury should determine credibility $^{78}$-is significantly undermined. And what is more, the defendant is not afforded a protective rule at the time of her trial.

Apart from the problems arising from the absence of a clear corroboration rule for trial courts to follow, there is another problem in this area of federal law. Not only are jurors unaware that they should search for evidence to corroborate the accomplice's testimony, they are also not consistently instructed to view such testimony with caution. ${ }^{79}$ Hence, their neutral assessment and unquestioning acceptance of the testimony as true ${ }^{80}$ is predictable since they have no reason for not viewing it as on par with that of other witnesses. Moreover, in the absence of mandatory cautionary jury instructions, appellate courts are burdened with the task of determining whether a particular set of instructions was adequate to ensure justice at the trial level. ${ }^{81}$ Understandably, the appellate decisions in this area have proved inconsistent and have generated uncertainty in trial courts.

The uncertainty stems from those courts that have reversed convictions yet have simultaneously afforded, through the promulgation of ambiguous standards, the opportunity for other courts to reach different conclusions. For example, in Tillery v. United States, ${ }^{82}$ the Fifth Circuit reversed a conviction

77. See cases cited supra notes 67-70.

78. See cases cited supra notes 58-64. As stated by the Ninth Circuit, "It is not for us to weigh the evidence or to determine the credibility of witnesses." Audett v. United States, 265 F.2d 837, 845 (9th Cir.) (quoting Glasser v. United States, 315 U.S. 60, 80 (1942)), cert. denied, 361 U.S. 815 (1959).

79. See cases cited supra notes 74-75; cases cited infra note 86.

80. See Tillery v. United States, 411 F.2d 644, 648 (5th Cir. 1969) ("By failing to warn the jury about [the accomplice's] reliability in this case, the trial court presented the evidence to the jury in an improper perspective, and the jury may have felt bound to accept it as true.").

81. See cases cited supra notes 58-64 \& 78; cases cited infra notes 84 \& 87 . In United States v. Kinnard, 465 F.2d 566 (D.C. Cir. 1972), Judge Bazelon advocated a mandatory instruction and voiced his concern that an innocent defendant may be convicted because a lawyer stumbled and neglected to request a cautionary jury instruction for an informer: "The rights of, in most cases, indigent defendants, should not be jeopardized by the inexperience or oversights of their appointed counsel." Id. at 573 .

82. 411 F.2d 644 (5th Cir. 1969). 
when both corroboration and instructions were lacking, because the question was a "crucial evidentiary one," meaning that the duty of a judge to provide cautionary instructions depends upon whether the accomplice's testimony constituted all, or a significant portion, of the evidence against the defendant. Despite repeated assertions by the legal community that jury instructions may tip the scale in close cases, ${ }^{83}$ the Tillery court and other appellate courts have avoided a prophylactic rule requiring the instruction. These courts have thus unnecessarily complicated this area of law, creating the need to review the significance of accomplice testimony in particular cases in order to assess what constitutes a "crucial evidentiary question." 84

As previously noted, in appellate decisions, courts have often reversed convictions when both corroboration and instructions were lacking, ${ }^{85}$ but not solely for failure to instruct. ${ }^{86}$ Not all courts, however, have adhered to this "either/or" standard; some have upheld a conviction in the absence of both corroboration and jury instructions. The inconsistency is illustrated in United States v. McCabe, ${ }^{87}$ where the Seventh Circuit refused to reverse a conviction after failure to give a cautionary jury instruction that was requested by the defense, even though corroboration was insufficient to overcome the inherent unreliability of the accomplice testimony. The court reasoned that although the refusal to give an instruction was error, the error was harmless because the accomplice's plea agreements were covered extensively in cross- and direct examinations, and the defense counsel emphasized the plea agreements in his closing testimony ${ }^{88}$ Thus, the court felt that "when pondering all that happened," the error of omitting the accomplice instruction did not prejudice the defendant. ${ }^{89}$ Likewise, in United States $v$. Anderson, ${ }^{90}$ the Eighth Circuit refused to reverse a conviction when the trial judge gave cautionary accomplice

83. In United States v. Becker, 62 F.2d 1007 (2d Cir. 1933), Judge Learned Hand acknowledged that in close cases, failure to give the warning "may turn the scale." Id. at 1009; see also Freed v. United States, 266 F. 1012, 1016 (D.C. Cir. 1920) (if court had brought character of government's witness to jury's attention, defendant's counsel would have been in better position to present his case and jury ruling might have been different).

84. Similar uncertain standards have been intimated in other decisions. See, e.g., United States v. Davis, 439 F.2d 1105, 1107 (9th Cir. 1971) (instructions needed when uncorroborated testimony is significant part of evidence).

85. United States v. Bernal, 814 F.2d 175, 183-85 (5th Cir. 1987); United States v. Owens, 460 F.2d 268, 269 (10th Cir. 1972); see also cases cited supra notes 58-64 \& 78.

86. United States v. Shriver, 838 F.2d 980, 983-84 (8th Cir. 1988); United States v. Kragness, 830 F.2d 842, 855 (8th Cir. 1987); United States v. McGinnis, 783 F.2d 755 (8th Cir. 1986); United States v. Gonzalez, 491 F.2d 1202 (5th Cir. 1974); see also cases cited supra note 74.

87. 720 F.2d 951 (7th Cir. 1983).

88. Id. at 957.

89. Id. To some extent the defendant is prejudiced because his protection against fabricated testimony is threatened when corroboration and jury instruction issues are decided not at the trial but at the appellate level, where the lower court decisions are viewed in the light most favorable to the government. "The verdict of a jury must be sustained if there is substantial evidence, taking the view most favorable to the Government, to support it." Audett v. United States, 265 F.2d 837, 845 (9th Cir.) (quoting Glasser v. United States, 315 U.S. 60,80 (1942)), cert. denied, 361 U.S. 815 (1959).

90. 654 F.2d 1264 (8th Cir. 1981). 
instructions for six witnesses but neglected to include the seventh witness, also an accomplice. Upon reviewing the facts of the case, the court did not find plain error, reasoning that it was clear that the witness was an accomplice. ${ }^{91}$

The Seventh and Eighth Circuits thus diverge from the majority of their counterparts that countenance the corroboration-jury instruction "either/or" standard. Even in the absence of both safeguards, these two circuits have held that a conviction can be upheld unless the trial record as a whole meets the plain error standard. In addition to fostering further inconsistency, they have necessitated yet another task: a court must determine when the facts of the case obviate the need not only for corroboration, but for jury instructions as well.

\section{PROPOSED REFORM}

This Note suggests that uniform legislative provisions ${ }^{92}$ defining an accomplice and establishing corroboration requirements for all accomplice testimony be included in the Federal Rules of Criminal Procedure, ${ }^{93}$ or, alternatively, in Title 18 of the United States Code ${ }^{94}$ or in the Federal Rules of Evidence. ${ }^{95}$ This Note further recommends the establishment of a rule requiring trial judges to provide cautionary jury instructions when an accomplice testifies. The following is a suggested rule of procedure that would provide much-needed clarity and certainty in the area of accomplice testimony:

An accomplice is a witness in a criminal action who may be liable to prosecution for, or may be considered to have participated in,

(a) the offense charged; or

(b) an offense based upon the same facts or conduct that consti-

tutes the offense charged against the defendant on trial in the

cause in which the testimony of the accomplice is given.

A conviction cannot be obtained upon testimony of an accomplice unless it is corroborated by such other evidence as shall tend to connect the defendant with the commission of the offense. ${ }^{96}$

This legislative provision could be implemented in the following manner. Upon hearing the evidence presented during the trial or, alternatively, at a pretrial hearing, the judge would render an initial determination as to whether

91. Id. at 1268.

92. Uniformity will be best achieved by legislative change. See Audett, 265 F.2d at 848 ("Any change of the rule should be made by Congressional legislation ... and not by judicial fiat, which, unless it be that of the Supreme Court, would affect certain federal courts only.").

93. The suggested rule could be incorporated into FED. R. CRM. P. 26.2, which governs the production of witness statements.

94. Part II of 18 U.S.C. addresses criminal procedure in the federal courts.

95. FED. R. EVD. 104 governs questions of admissibility in the federal courts.

96. By defining corroboration as such, the rule would prevent a defendant from being convicted solely upon testimony provided by an accomplice. That is, the prosecution must offer other extrinsic evidence to establish the defendant's guilt. $C f$. statutes cited supra note 47 (New York and California). 
the witness is an accomplice and whether there is corroboration. Thus, she would be responsible for assessing the evidentiary technicalities, a task more easily performed by judge than jury. ${ }^{97}$ If the judge decided the witness was an accomplice but did not find his testimony to be corroborated, she would not permit a jury to consider it. On the other hand, if she did find the witness testimony to be corroborated, she would allow the evidence to go to a jury. ${ }^{98}$ In the latter case, she would instruct the jury to determine whether the witness is an accomplice and whether his testimony is corroborated. In effect, then, if the testimony survived the scrutiny of the judge, the jury would function as a second trier of fact with respect to whether there existed corroborated accomplice testimony. Furthermore, under this scheme, in cases in which a jury considered accomplice testimony, the judge would provide a cautionary jury instruction as to how to weigh the testimony. An instruction similar to the following would alert the jury to the danger of unquestioningly accepting accomplice testimony:

The jury should keep in mind that the testimony of an accomplice should be closely examined for credibility. You should weigh his testimony with scrutiny, bearing in mind his reasons for testifying, the strength of the corroborating evidence, and the fact that he is in a position to present what you might consider to be especially believable testimony as a result of his intimate involvement with the crime alleged against the defendant.

Corroboration itself does not negate the need for a mandatory jury instruction such as the aforementioned. False accomplice testimony may still occur even though corroboration is presented; that is, corroborative evidence may be presented by the prosecutor to establish the defendant's connection to the crime, but there still may not be sufficient evidence to substantiate the accomplice testimony, since often only the accomplice and the defendant know what occurred behind the scenes. ${ }^{99}$ A cautionary jury instruction is, therefore, a necessary security measure against false testimony in all cases in which an accomplice testifies.

97. See Comment, Corroborating Confessions: An Empirical Analysis of Legal Safeguards Against False Confessions, 1984 WIS. L. REv. 1121, 1141 [hereinafter Comment, Corroborating Confessions]; Note, Confession Corroboration in New York: A Replacement for the Corpus Delicti Rule, 46 FORDHAM L. REV. 1205,1211 n.34 (1978).

98. By allowing the jury to hear the accomplice testimony before the judge rules on the corroboration issue, the defendant is not prejudiced. In other words, even if the jury hears the testimony, uncorroborated accomplice testimony, under this Note's proposal, is not enough to convict the defendant. Therefore, the judge will dismiss the case and any claums of prejudice will be moot.

99. An example illustrates this point. Assume that the accused was involved peripherally because he was at the scene of the crime, and, although innocent of the crime alleged, did have a motive for committing it. Further assume that his presence and motive are considered to be corroborating circumstances. In this situation, the existence of corroboration itself may provide an opportunity for the perjurious accomplice to shift the blame. Hence, the cautionary instruction is still needed. 


\section{A. Rule of Sufficiency}

The accomplice corroboration rule proposed above can be viewed as a rule of sufficiency by way of analogy to the corroboration rule that currently exists for confessions and admissions. In Opper v. United States, ${ }^{100}$ the Supreme Court held that confessions, admissions, and exculpatory statements must be corroborated by "substantial independent evidence which would tend to establish the trustworthiness of the statement." ${ }^{101}$ This rule, created as it was by decisional law, ${ }^{102}$ has been viewed by commentators and the courts as a rule of sufficiency; ${ }^{103}$ an uncorroborated confession cannot support a conviction in the absence of independent evidence of the facts admitted. ${ }^{104}$ Thus, without corroborative evidence supporting a conviction beyond a reasonable doubt, the judge must render a judgment of acquittal for the defendant. ${ }^{105}$ As applied to accomplice testimony, such a rule would similarly require a judge to render a judgment of acquittal if the prosecution had no corroborating evidence of the defendant's guilt.

The current treatment of confessions by the state and federal courts is similar to the suggested reform for accomplice testimony. Nearly all states require the judge initially to assess the presence of corroboration in confession cases. ${ }^{106}$ In some states, the judge, upon finding corroboration, submits the confession to a second trier of fact, the jury, advising it to make a finding on corroboration; if the jurors do not find any, the defendant must be acquitted. The role of judge and jury in the federal courts vis-á-vis confessions is somewhat less clear, ${ }^{107}$ although some case law indicates that the judge determines the sufficiency of corroboration. ${ }^{108}$

100. 348 U.S. 84 (1954).

101. Id. at 93 . For a thorough discussion of the corroboration rule for confessions, see Comment, supra note 97.

102. Congress has not yet enacted legislative provisions addressing corroboration of confessions. One reason for not enacting legislation may be that other safeguards have been created for the reliability of confessions. For example, before a confession is admitted into evidence, a separate hearing outside the presence of the jury is conducted to determine whether the confession was voluntary. FED. R. EVID. 104 (C). Additionally, courts must abide by the Miranda doctrine to ensure the voluntariness of confessions. Miranda v. Arizona, 384 U.S. 436 (1966). Although it is also considered to be presumptively unreliable, no similar safeguards are applied to accomplice testimony.

103. United States v. Bukowski, 435 F.2d 1094, 1105 (9th Cir. 1970) (corroboration rule tests sufficiency of evidence); Note, supra note 97, at 1210-11 (corroboration rule is rule of sufficiency). (1956).

104. Annotation, Corroboration of Extrajudicial Confessions or Admissions, 45 A.L.R. 2d 1319-25

105. FED. R. CRIM. P. 29 governs motions for judgment of acquittal.

106. For specifics regarding state treatment of corroboration requirements, see Comment, Corroborating Confessions, supra note 97, at 1136-41.

107. See Developments in the Law-Confessions, 79 HARV. L. REV. 935, 1081 (1966) (no established state or federal rule governing distribution of functions between judge and jury).

108. In Smith v. United States, 348 U.S. 147, 159 (1954), the Court held that there was sufficient corroboration of an extrajudicial admission to permit the case to go to the jury. Thus, the Court appears to have viewed the rule as a test of sufficiency for the trial judge. In United States v. Calderon, 348 U.S. $160,163-64$ (1954), the Court explicitly held that the trial judge should determine corroboration of an admission. In Iva Ikuko Toguri D'Aquino v. United States, 192 F.2d 338, 357 (9th Cir. 1951), the court 


\section{B. Rule of Admissibility}

The proposed rule could also be implemented as one of admissibility. Under Rule 104 of the Federal Rules of Evidence, the judge decides preliminary questions, which include questions of admissibility. Rule 104(c), in particular, provides that a hearing on the admissibility of a confession, which depends upon the voluntariness of the confession, must be held outside the presence of the jury. The application of this rule by the federal courts supports this Note's argument that an accomplice corroboration rule could also profitably be viewed as a rule of admissibility, according to which the judge would decide if the accomplice testimony should be admitted into evidence for the jury's consideration.

The Supreme Court has allocated the functions of judge and jury when questions arise as to the voluntariness and therefore the admissibility of a confession. In Jackson v. Denno, ${ }^{109}$ the Court indicated that two allocations were constitutionally permissible. Under the first, which is considered the more orthodox approach, the voluntariness of a confession is for the judge alone to decide, and only upon a finding of voluntariness can he submit the confession to the jury. ${ }^{110}$ Under the second constitutionally permissible view, known as the "Massachusetts procedure," the judge makes a finding and admits only voluntary testimony. The judge, however, still instructs the jurors to evaluate the confession and to distegard it if the jurors find that it was involuntary. ${ }^{111}$ The latter method is similar to this Note's proposal in that after finding the requisite voluntariness as a preliminary matter, and after admitting the testimony, the judge provides cautionary instructions to the jury. Thus, the issue of voluntariness - or for our purposes, the issue of corroboration —is not entirely removed from the ambit of jury consideration.

In sum, the proposed corroboration provision can be conceptualized as either a rule of sufficiency or one of admissibility. Under either model, the judge would determine whether the witness was an accomplice and whether her testimony was corroborated. If there were no corroboration there would, by definition, be no evidence against the defendant other than the accomplice testimony itself, so the defendant would be acquitted. Having found the requisite corroboration, however, the judge would submit the testimony to the jury with an instruction that would caution it to evaluate the witness' status and to confirm the existence of corroboration. By adopting this scheme, the federal

held that refusal to give a requested instruction did not require reversal because there was substantial proof of the crime apart from the defendant's admissions. The court left open the issue of whether refusal to give an instruction absent other evidence of guilt would result in reversal.

109. 378 U.S. 368 (1964).

110. Id. at 378 .

111. Id. It is noteworthy that the Court also held that New York's procedure, which left the entire issue of voluntariness to the jury, was not constitutionally permissible because it did not afford a reliable determination of voluntariness that would adequately protect a defendant. Id. at 389. 
system would provide some protection against false accomplice testimony. As a sufficiency rule, uncorroborated testimony would not be sufficient for conviction and the judge would render a judgment of acquittal for the defendant. Similarly, as a rule of admissibility, uncorroborated testimony would not be admissible for consideration by a jury and the judge would also render a judgment of acquittal.

\section{The Case for Corroboration}

One criticism of a procedure according to which the admissibility of accomplice testimony is determined at a pretrial hearing rather than at the end of the trial and immediately prior to jury deliberation might be posited as follows: to conduct a pretrial hearing to determine corroboration of accomplice testimony raises problems that might not arise in conducting such a hearing to determine the voluntariness of a confession. Most importantly, during a pretrial hearing to assess corroboration, the prosecution might have to reveal considerable portions of its evidence and strategy to defense counsel. A hearing to determine the admissibility of a confession, in contrast, reveals only the circumstances surrounding the confession, and not the other facets of the case. On the other hand, one might argue that to render a ruling on the accomplice testimony at the conclusion of the trial is unfair to the defendant, since, even if the jurors are instructed to disregard the testimony, the fact that they were exposed to it during the trial might unduly prejudice the defendant. ${ }^{12}$

These criticisms are phantom concerns, however. To begin with, a finding of lack of corroboration amounts to a determination that there is no independent evidence to connect the defendant to the crime, and, therefore, a judgment of acquittal will ensue. ${ }^{113}$ Furthermore, given that the pretrial hearing would be conducted shortly before the trial and that most of the evidence the government intended to offer would have already been provided to the defense in discovery, there can be little fear that the government's case will be "revealed." Finally, the courts have created and routinely use a similar pretrial procedure called a Kastigar hearing. The Kastigar hearing allows the government, when it wishes to prosecute a witness for acts concerning which he has provided immunized testimony, to prove that its evidence was not derived from the immunized testimony. ${ }^{114}$

112. See supra note 98.

113. See supra note 96.

114. To prosecute the previously immunized witness, the government must prove that the evidence relied on to charge and convict the witness is obtained from independent sources. Kastigar v. United States, 406 U.S. 441, 461 (1972). Courts usually employ a pretrial evidentiary hearing to test the government's evidence for taint. Inevitably, in this hearing, the government must reveal at least some portions of its evidence, or at least the circumstances in which the evidence was obtained, before the judge can render a ruling as to its admissability. See, e.g., United States v. Romano, 583 F.2d 1, 3 (1st Cir. 1978) (three-day taint hearing held); United States v. McDaniel, 482 F.2d 305, 311-12 (8th Cir. 1973) (pretrial hearing needed for independent source test); see also supra note 33 . 
Another criticism advanced by some legal scholars and practitioners ${ }^{115}$ is that corroboration requirements would impede criminal prosecutions, especially those involving organized crime, when accomplice testimony is especially crucial. ${ }^{116}$ This appears to be an exaggerated concern. First, the proposed reform does not argue for a per se rule prohibiting all use of accomplice testimony, but rather recommends that such testimony be strengthened to ensure its truthfulness. Second, in light of the increased availability of law enforcement tools resulting from technological advances, ${ }^{117}$ corroboration requirements should not seriously interfere with prosecutorial goals. Rather than impeding prosecutions, the requirements will motivate federal agents, who often work directly with the prosecutors, to conduct a more thorough investigation. ${ }^{118}$ For the same reasons that extrinsic evidence has been recognized as more reliable than confessional evidence, ${ }^{119}$ federal judges and jurors ought to view evidence obtained through skillful and planned investigative efforts more favorably than the unsubstantiated testimony of accomplice witnesses.

A final argument against mandatory jury instructions is that rulemaking reduces the discretion of trial judges. But one need only point to the many appeals resulting from the current approach to demonstrate that such discretion does not always breed efficiency or, more importantly, fairness to the defendant. Second-guessing by the appellate courts as to the propriety of the admission of accomplice testimony at trial in fact undermines the role of trial courts.

By implementing these evidentiary safeguards, the truthfinding function of federal criminal trials would be enhanced and innocent defendants would be afforded greater protection. Corroboration requirements would reduce the incentives and opportunities for false testimony, thereby filling the gap caused by the inadequacy of the perjury sanction. ${ }^{120}$ Although use immunity and contingent plea agreements are recognized as valid law enforcement tools, ${ }^{121}$

115. See supra note 49.

116. This necessity argument has been addressed by courts when dealing with the admissibility of coconspirator statements. The Supreme Court, in California v. Green, 399 U.S. 149, 167 n.16(1970), has noted that the necessity rationale for using the statements has nothing to do with the reliability of the testimony. On the contrary, use of the statements may be unsatisfactory because they may result in convictions based on unreliable evidence. For further discussion of the necessity argument, see Note, Federal Rule of Evidence $801(d)(2)(E)$ and the Confrontation Clause: Closing the Window of Admissibility for Co-conspirator Hearsay, 53 FORDHAM L. REV, 1291, 1298 n.40 (1985).

117. One major technological advance is the use of electronic surveillance techniques that record oral, wire, and electronic communications. The number of federal authorizations for these interceptions has increased from 33 per year in 1969 to 236 in 1987. DEPARTMENT OF JUSTICE, supra note 9, at 528 table 5.2. In 1987, over 2700 arrests and convictions resulted from these interceptions. Id. at 530 table 5.4.

118. A similar argument has been used to justify corroboration requirements established for confessions. See generally Comment, Corroborating Confessions, supra note 97.

119. This view, which has been expressed in confession cases, is also applicable here. See Escobedo v. Ilinois, 378 U.S. 478, 488-89 (1964) (system of law enforcement dependent upon confessions will be less reliable than one dependent upon extrinsic evidence secured through skillful investigative techniques).

120. See supra text accompanying notes 18-23.

121. See sources cited supra note 29 . 
the search for the truth within the context of immunity ${ }^{122}$ is better maintained when there is corroboration to support questionable testimony.

The proposed changes would also explicitly demarcate the proper roles of trial and appellate courts. Trial courts would assess the presence of corroboration by applying a clearly established rule, and appellate courts would no longer be burdened with the task of "creating" corroboration standards. ${ }^{123}$ Likewise, mandatory jury instructions would eliminate the reviewing courts' burden of evaluating the trial courts' omission of such instructions. ${ }^{124}$ Thus, the difficulty of applying ambiguous standards ${ }^{125}$ (created by the reviewing courts themselves) in order to discern the need for jury instructions and distinguish between testimony that did and did not prejudice the defendant ${ }^{126}$ would be obviated by the brightline functions delegated to trial judges. ${ }^{127}$.

\section{CONCLUSION}

Many unnecessary criminal appeals questioning the sufficiency of an accomplice's testimony and the trial court's treatment of such testimony have resulted from the absence of uniform legislative provisions or judicial standards addressing corroboration. In fact, the standards established to date have intensified rather than alleviated uncertainty about the treatment afforded accomplice testimony by the federal courts. Because the reviewing courts do not apply uniform criteria to accomplice testimony, the protection against false testimony remains haphazard. Such variability increases the probability of convicting innocent defendants. Without reform, these miscarriages of justice will doubtless continue.

Requiring corroboration of accomplice testimony is a desirable and, as demonstrated by this Note, viable, method of reform. Adoption of a corroboration rule, in conjunction with a requirement that all judges provide a cautionary jury instruction when an accomplice testifies, would be an efficient means of affording defendants the protection our judicial system values.

122. "The very purpose of the granting of immunity is to reach the truth . ..." United States v. Tramunti, 500 F.2d 1334, 1343 (2d Cir.), cert. denied, 419 U.S. 1079 (1974).

123. See cases cited supra notes 69-70.

124. See supra notes 74-75 \& 85-86 and accompanying text.

125. See supra note 82 and accompanying text.

126. See supra notes $87-89$ and accompanying text. With the issues of corroboration and jury instructions decided at the trial level, the defense no longer has to wait until an appeal-when the facts are viewed in the light most favorable to the prosecution-to question the reliability of the accomplice's testimony or the omission of cautionary jury instructions.

127. Such a duty is not an unreasonable burden. See United States v. Kinnard, 465 F.2d 566, 573 (D.C. Cir. 1972) (placing duty on trial court saves time and reduces number of appeals premised on failure of defense counsel to request instruction). 